\title{
Effectiveness of Bilateral Greater and Lesser Occipital Nerve Blocks in the Prophylaxis of Episodic Migraine
}

\author{
Epizodik Migren Profilaksisinde Bilateral Büyük ve Küçük Oksipital Sinir Bloğunun Etkinliği
}

\author{
Muzaffer GÜNEŞ ${ }^{1}$ \\ (i) 0000-0002-9325-1292 \\ Ersin ÖZEREN ${ }^{2}$ \\ (D) 0000-0001-9861-274X
}

\begin{abstract}
Aim: In recent years, many studies have been conducted on the effectiveness of occipital nerve block (ONB) especially in the prophylaxis of chronic migraine. In this study, it was aimed to investigate the effectiveness of bilateral greater and lesser ONBs in the prophylaxis of episodic migraine without aura.

Material and Methods: This retrospective study included patients with episodic migraine without aura who underwent bilateral greater and lesser ONBs between January 2018 and December 2019. Information about headache frequency, attack duration, and pain severity (VAS score) of the patients in the last month before nerve block and 1 month after nerve block was retrieved from the database and recorded for statistical analysis.

Results: A total of 17 patients aged 26-57 years were included in this study. None of the patients developed any drug side effects or complications associated with ONB. With ONB, the median value of headache attack frequency dropped from 5 (range, 4-14) to 2 (range, 0-6) per month $(\mathrm{p}=0.001)$, the median value of pain duration dropped from 12 (range, 6-14) to 4 (range, 0-9) days $(\mathrm{p}<0.001)$, and the median value of VAS pain severity score dropped from 9 (range, 7-10) to 5 (range, $0-10)$ for the patients ( $\mathrm{p}=0.001$ ), compared with the pretreatment values.

Conclusion: Bilateral greater and lesser ONBs are effective in the prophylaxis of episodic migraine without aura. ONB can be considered as a treatment option in patients with episodic migraine without aura who do not respond to conventional treatments (oral drugs) or do not accept conventional therapy.
\end{abstract}

Keywords: Occipital nerve block; episodic migraine without aura; headache; prophylactic treatment.

\section{ÖZ}

Amaç: Son yıllarda oksipital sinir bloğunun (OSB) özellikle kronik migren profilaksisindeki etkinliği konusunda çok sayıda çalışma yapılmıştır. Bu çalışmada, epizodik aurasız migren profilaksisinde bilateral büyük ve küçük OSB'nin etkinliğinin araştırılması amaçlanmıştır.

Gereç ve Yöntemler: Bu geriye dönük çalışmaya, Ocak 2018 ile Aralık 2019 tarihleri arasında bilateral büyük ve küçük OSB uygulanmış olan epizodik aurasız migren hastaları dahil edilmiştir. Hastaların sinir bloğu uygulanmadan önceki son ay ile sinir bloğu uygulandıktan sonraki bir aylık baş ağrısı sıklığı, atak süresi ve ağrı şiddeti (VAS skoru) hakkındaki bilgileri veri tabanından alındı ve istatistiksel analiz için kaydedildi.

Bulgular: Bu çalışmaya yaşı 26 ile 57 yıl arasında olan toplam 17 hasta dahil edilmiştir. Hastaların hiçbirinde OSB ile ilişkili herhangi bir ilaç yan etkisi ya da komplikasyon gelişmemişti. Tedavi öncesi değerler ile karşılaştırıldığında, hastaların OSB ile baş ağrısı atak sıklığının medyan değeri ayda 5 (aralık, 4-14)'ten 2 (aralık, 0-6)'ye $(\mathrm{p}=0,001)$, ağrı süresinin medyan değeri 12 (aralık, 6-14)'den $4(\operatorname{aral1k}, 0-9)$ güne $(\mathrm{p}<0,001)$ ve son olarak VAS ağrı şiddeti skoru medyan değeri ise 9 (aralık, 7-10)'dan 5 (aralık, 0-10)'e düşmüştü ( $\mathrm{p}=0,001$ ). Sonuç: Bilateral büyük ve küçük OSB epizodik aurasız migren profilaksisinde etkilidir. Konvansiyonel (oral ilaçlar) tedavilere yanıt vermeyen veya konvansiyonel tedaviyi kabul etmeyen epizodik aurasız migreni olan hastalarda OSB bir tedavi seçeneği olarak düşünülebilir. Anahtar kelimeler: Oksipital sinir bloğu; epizodik aurasız migren; baş ağrısı; profilaktik tedavi.

Received / Gelis Tarihi : 14.01.2021

Accepted / Kabul Tarihi : 17.04.2021

Available Online /

Preliminary results of this study was presented as an oral presentation at the $5^{\text {th }}$ International Hippocrates

Çevrimiçi Yayın Tarihi : 22.04.2021 Congress on Medical and Health Sciences (December 18-19, 2020) 


\section{INTRODUCTION}

Migraine is a common headache disorder with an annual prevalence of $16.4 \%$ in Turkey. It is more common in female $(8.5 \%$ in male, $24.6 \%$ in female), especially between the ages of 35-40 (1). Chronic migraine is defined as a headache that has occurred for $>3$ months with a frequency of $\geq 15$ days per month, with a migraine headache at least 8 days per month. Otherwise, if a headache occurs $<15$ days per month in a patient with migraine, it is defined as episodic migraine (2). Occipital nerve block (ONB) has been used as a peripheral nerve block method for a long time. Numerous studies have been conducted on its use in the treatment of migraine $(3,4)$. Most of these studies have focused on chronic migraine and the greater occipital nerve (4-6). However, as far as we have investigated in the literature, no data have been found regarding the effectiveness of bilateral greater and lesser ONBs in the prophylaxis of episodic migraine without aura. This situation has led us to design this study.

In this study, it was aimed to investigate the effectiveness of bilateral greater and lesser ONBs performed with a mixture of methylprednisolone, prilocaine, and bupivacaine in the prophylactic treatment of episodic migraine without aura.

\section{MATERIAL AND METHODS}

This retrospective study included patients with migraine who underwent bilateral greater and lesser ONBs at the Neurology and Neurosurgery Clinic, Aksaray University Training and Research Hospital, between January 2018 and December 2019. Among these patients, those aged $>18$ years, who were diagnosed with episodic migraine without aura according to the International Classification of Headache Disorders (ICHD-3) beta version (7), had >4 headache attacks per month with an attack duration of at least 1 day, and whose pain score according to the Visual Analog Scale (VAS) was severe (VAS >6) were included in the study. Patients who had previously undergone ONB and those with bleeding diathesis, local active infection in the occipital region or systemic infection, uncontrolled diabetes mellitus, uncontrolled hypertension, liver disease, congestive heart failure, history of psychiatric disease, and renal failure, as well as alcohol or substance addiction, antiaggregant or anticoagulant use, history of cranial and occipital surgery, coronary artery disease, history of allergic reaction to the drugs to be administered, and those who were pregnant and breastfeeding were excluded from the study.

Before ONB was administered, all patients were using at least one of the migraine prophylactic drugs (flunarizine, topiramate, amitriptyline, and propranolol) regularly for at least 6 months. Bilateral greater and lesser ONBs were performed after all patients were given detailed information about the procedure to be performed along with its risks, and their consents were obtained. There is no established consensus about the method of ONB. When the literature is examined, it can be seen that it was done with many different methods (3). Our application method is as follows: A 10-ml mixture consisting of $1 \mathrm{ml}$ methylprednisolone acetate $(40 \mathrm{mg} / \mathrm{ml}), 4 \mathrm{ml} 2 \%$ prilocaine hydrochloride $(20 \mathrm{mg} / \mathrm{ml})$, and $5 \mathrm{ml} 0.5 \%$ bupivacaine hydrochloride $(5 \mathrm{mg} / \mathrm{ml})$ was prepared; bilateral greater and lesser occipital nerve areas were determined; and each area was injected with $2.5 \mathrm{ml}$ of the mixture using a 25 gauge, $90-\mathrm{mm}$ spinal needle in each session in patients who accepted ONB treatment and from whom consent was obtained. Precautions were taken in terms of possible allergic reactions and complications, and patients were kept under observation for $1 \mathrm{~h}$ after the procedure. ONB was applied in three sessions, once every 15 days (on days 0,15 , and 30) in the first month. When the expected effect was not observed in patients who were called to the neurology outpatient clinic for follow-up 1 month after the last session (at least $50 \%$ reduction in the frequency, duration, and severity of attacks was taken as a criterion for treatment success), an additional $4^{\text {th }}$ session of ONB was performed using the same procedure. Patients were given detailed information and asked to keep a monthly headache diary, including headache frequency, pain severity, and duration. Patients who underwent ONB were followed up for 3 months.

We used the information from our database regarding the headache frequencies, attack duration, and pain severity of the patients in the last month before nerve block was performed and in the third month after nerve block was performed for statistical analysis.

The study was approved by the Aksaray University Ethics Committee (December 18, 2020, 13-23) and the study was conducted in accordance with the Declaration of Helsinki. Statistical Analysis

The Shapiro-Wilk test was used to examine the distribution pattern of the data. The Wilcoxon test was used to evaluate the effectiveness of ONB since data not distributed normally. Descriptive statistics were presented with median, quartiles and minimum-maximum. Statistical analyses were performed using SPSS v.23.0 software for Windows. $p<0.05$ was considered statistically significant.

\section{RESULTS}

Of the 252 migraine patients followed in our outpatient clinic, a total of 17 patients, including 15 female and two male patients, who received ONB treatment, were included in the study. The median age of the patients was 37 (range, 26-57). The median disease duration of the patients was 7.5 years (range, 1-30).

In Table 1, the comparison of frequency, duration, and severity of the patients' headaches before and after bilateral greater and lesser ONBs is shown. The median headache frequency of the patients was 5 (range, 4-14) per month before treatment, whereas it was 2 (range, 0-6) after $\mathrm{ONB}$, and this was statistically significant $(\mathrm{p}=0.001)$. While the median duration of pain before ONB was 12 (range, 6-14) days/month, it was found to be 4 (range, 0-9) days/month after ONB, and this was statistically significant $(p<0.001)$. Finally, with ONB treatment, the median VAS pain severity score of the patients was decreased statistically significantly $(\mathrm{p}=0.001)$ from 9 (range, 7-10) to 5 (range, 0-10).

\section{DISCUSSION}

In the present study, we found that the VAS score and the severity and frequency of pain significantly decreased after ONB in patients with episodic migraine without aura. In previous studies, ONB was performed for the bilateral greater occipital nerve $(4-6,8)$. In this study, bilateral nerve 
Table 1. Comparison of the headache frequency, attack duration, and pain severity before and after ONB

\begin{tabular}{lccc} 
& Before ONB & After ONB & p \\
\hline Headache frequency (day/month) & $5(4-6.5)[4-14]$ & $2(1-3)[0-6]$ & $\mathbf{0 . 0 0 1}$ \\
Duration of headache (day) & $12(10-14)[6-14]$ & $4(1.25-5.5)[0-9]$ & $<\mathbf{0 . 0 0 1}$ \\
Headache severity (VAS score) & $9(8-10)[7-10]$ & $5(4-7)[0-10]$ & $\mathbf{0 . 0 0 1}$ \\
\hline
\end{tabular}

ONB: occipital nerve block, VAS: visual analog scale, descriptive statistics were presented as median $\left(1^{\text {st }}-3^{\text {rd }}\right.$ quartiles $)$ [minimum-maximum]

block was performed for both greater and lesser occipital nerves. In addition, although there is no consensus in the literature for ONB (9), we used a mixture of methylprednisolone, prilocaine, and bupivacaine.

There are many studies on the effectiveness of ONB in chronic migraine prophylaxis (4-6). On the other hand, there are a few studies investigating the effectiveness of ONB in the prophylaxis of episodic migraine without aura $(10,11)$. In a randomized, double-blind, and placebocontrolled study by Dilli et al. (10), which included patients with both episodic and chronic migraine together, a single greater ONB did not provide a short-term protective effect on moderate and severe migraine days compared with placebo in patients with episodic or chronic migraine. However, Dilli et al. (10) did not differentiate between the patients as episodic and chronic, and they performed a greater ONB only once. In a single-blind, randomized, and placebo-controlled study of greater occipital and supraorbital nerve block by Özer et al. (11), they showed that greater ONB and supraorbital nerve block with lidocaine was more effective than placebo in the prophylactic treatment of both episodic and chronic migraine. In the present study, we found that bilateral greater and lesser ONBs that we applied in three sessions (with a mixture of methylprednisolone, prilocaine, and bupivacaine) at 15-day intervals were effective and safe in the prophylaxis of episodic migraine without aura.

In the literature, development of complications or drug side effects during ONB has been reported in a small number of patients (3). Most of these were mild or transient effects (3). No drug side effects or complications developed during or after nerve block procedure in the patients in the present study. Drug side effects or complications are more likely to occur in studies with much larger numbers of patients. The patient should nevertheless be informed in detail about the effects that may occur with ONB, and the clinician applying the treatment should be prepared in this respect.

This study is an important study for providing new information to the literature due to the fact that nerve block was performed for both bilateral greater and lesser occipital nerves and that it was conducted only in episodic migraine without aura. Nevertheless, this study has few limitations. First, the study was conducted on a small number of patients and was retrospective. Second, we did not follow up the patients for $>3$ months after ONB.

\section{CONCLUSION}

Based on the results of this study, it has been considered that bilateral greater and lesser ONBs are effective and safe in the prophylaxis of episodic migraine without aura. ONB can be considered as a treatment option in patients with episodic migraine without aura who do not respond to conventional treatments (oral drugs) or do not accept conventional therapy.
Ethics Committee Approval: The study was approved by the Ethics Committee of Aksaray University Faculty of Medicine (18.12.2020, 13-23).

Conflict of Interest: None declared by the authors.

Financial Disclosure: None declared by the authors.

Acknowledgements: The authors would like to thank Assoc. Prof. Dr. P. Güneş. The authors would also like to thank Enago - https://www.enago.com.tr/ceviri/ for their assistance in manuscript translation and editing.

Author Contributions: Idea/Concept: MG; Design: MG; Data Collection/Processing: MG, EÖ; Analysis/Interpretation: MG, EÖ; Literature Review: MG, EÖ; Drafting/Writing: MG; Critical Review: EÖ.

\section{REFERENCES}

1. Ertas M, Baykan B, Orhan EK, Zarifoglu M, Karli N, Saip S, et al. One-year prevalence and the impact of migraine and tension-type headache in Turkey: a nationwide home-based study in adults. J Headache Pain. 2012;13(2):147-57.

2. Headache Classification Committee of the International Headache Society (IHS). The International Classification of Headache Disorders, 3rd edition. Cephalalgia. 2018;38(1):1-211.

3. Inan LE, Inan N, Unal-Artık HA, Atac C, Babaoglu G. Greater occipital nerve block in migraine prophylaxis: Narrative review. Cephalalgia. 2019;39(7):908-20.

4. Gul HL, Ozon AO, Karadas O, Koc G, Inan LE. The efficacy of greater occipital nerve blockade in chronic migraine: A placebo-controlled study. Acta Neurol Scand. 2017;136(2):138-44.

5. Cuadrado ML, Aledo-Serrano Á, Navarro P, LópezRuiz P, Fernández-de-Las-Peñas C, González-Suárez I, et al. Short-term effects of greater occipital nerve blocks in chronic migraine: A double-blind, randomised, placebo-controlled clinical trial. Cephalalgia. 2017;37(9):864-72.

6. Inan LE, Inan N, Karadaş Ö, Gül HL, Erdemoğlu AK, Türkel Y, et al. Greater occipital nerve blockade for the treatment of chronic migraine: A randomized, multicenter, double-blind, and placebo-controlled study. Acta Neurol Scand. 2015;132(4):270-7.

7. Headache Classification Committee of the International Headache Society (IHS). The International Classification of Headache Disorders, 3rd edition (beta version). Cephalalgia. 2013;33(9):629808.

8. Friedman BW, Mohamed S, Robbins MS, Irizarry E, Tarsia V, Pearlman S, et al. A randomized, shamcontrolled trial of bilateral greater occipital nerve blocks with bupivacaine for acute migraine patients 
refractory to standard emergency department treatment with metoclopramide. Headache. 2018;58(9):1427-34.

9. Tang Y, Kang J, Zhang Y, Zhang X. Influence of greater occipital nerve block on pain severity in migraine patients: A systematic review and metaanalysis. Am J Emerg Med. 2017;35(11):1750-4.

10. Dilli E, Halker R, Vargas B, Hentz J, Radam T, Rogers $\mathrm{R}$, et al. Occipital nerve block for the short-term preventive treatment of migraine: A randomized, double-blinded, placebo-controlled study. Cephalalgia. 2015;35(11):959-68.

11. Özer D, Bölük C, Türk Börü Ü, Altun D, Taşdemir M, Köseoğlu Toksoy C. Greater occipital and supraorbital nerve blockade for the preventive treatment of migraine: a single-blind, randomized, placebo-controlled study. Curr Med Res Opin. 2019;35(5):909-15. 